\title{
Climate risk services for cereal farming
}

\author{
Anne Gobin ${ }^{1,2}$, Nicoletta Addimando ${ }^{3}$, Christoph Ramshorn ${ }^{3}$, and Karl Gutbrod ${ }^{3}$ \\ ${ }^{1}$ Flemish Institute for Technological Research VITO nv, 2400 Mol, Belgium \\ ${ }^{2}$ Department of Earth \& Environmental Sciences, Faculty of BioScience Engineering, \\ KU Leuven, 3001 Heverlee, Belgium \\ ${ }^{3}$ meteoblue AG, 4058 Basel, Switzerland
}

Correspondence: Anne Gobin (anne.gobin@ vito.be)

Received: 10 November 2020 - Revised: 15 February 2021 - Accepted: 21 February 2021 - Published: 15 March 2021

\begin{abstract}
Agricultural production is largely determined by weather conditions during the crop growing season. An important aspect of crop yield estimation concerns crop growth development. The occurrence of meteorological events such as frosts, droughts or heat stress during the crop life cycle or during certain phenological stages helps explain yield fluctuations of common arable crops. We developed a methodology and visualisation tool for risk assessment, and tested the workflow for drought and frost risk for winter wheat, winter barley and grain maize in Belgium. The methodology has the potential to be extended to other extreme weather events and their impacts on crop growth in different regions of the world.
\end{abstract}

\section{Introduction}

Climate change has already had a marked influence on many farming systems worldwide (Bindi and Olesen, 2011; Trnka et al., 2016; Kahiluoto et al., 2019). The impacts of the 2003 heat wave in Europe with temperatures up to $6{ }^{\circ} \mathrm{C}$ above long-term means, and precipitation deficits up to $300 \mathrm{~mm}$ (Trenberth et al., 2007) resulted in an estimated loss of EUR 13 billion for the European agricultural sector (Ciais et al., 2005). Heat waves such as the summer of 2003 are not unusual if compared to future climate simulations towards the end of the century (Schär et al., 2004) and are heavily influenced by soil moisture-temperature interactions (Fischer et al., 2007).

Cropping systems are managed with substantial inputs and technological improvements that have in most years outweighed the impacts of climate change (Reidsma et al., 2009). Nevertheless extreme events have significant impacts on agricultural production (e.g. for wheat see Mäkinen et al., 2018; Kahiluoto et al., 2019) and pose severe limitations to agro-ecosystem functioning and ultimately on sustainable agricultural land management. Therefore the application of climate services has received attention in many parts of Europe (Termonia et al., 2018). With climate being the average weather type during a period of minimum 30 years, effects are on a temporal scale that is unusual to agricultural decision making and farmers' annual activities are therefore not tracking the speed of climate change. Changes in air temperature and rainfall have already resulted in increases in frequency and intensity of extreme events with long-term implications for the viability of agro-ecosystems, such as drought impacts on grassland (Zamani et al., 2015; Vanwindekens et al., 2018) or late frost impacts on apple and pear cultivation (Drepper et al., 2020).

The major objective of this research is to develop a methodology for assessing climate risks and application services for arable farming. The overlap between sensitive crop phenological stages with extreme events was assessed in terms of risk as composed of likelihood and impact on the growth stage. We tested the methodology and developed a visualisation tool for drought and frost risk for winter wheat, winter barley and grain maize in Belgium.

\section{Materials and methods}

The modelling framework included crop growth and development, water balance and subsequent risk assessment of extreme weather events. The temporal overlap between weather conditions and crop stages in arable cropping systems was determined using a model that couples phenology to the soil 

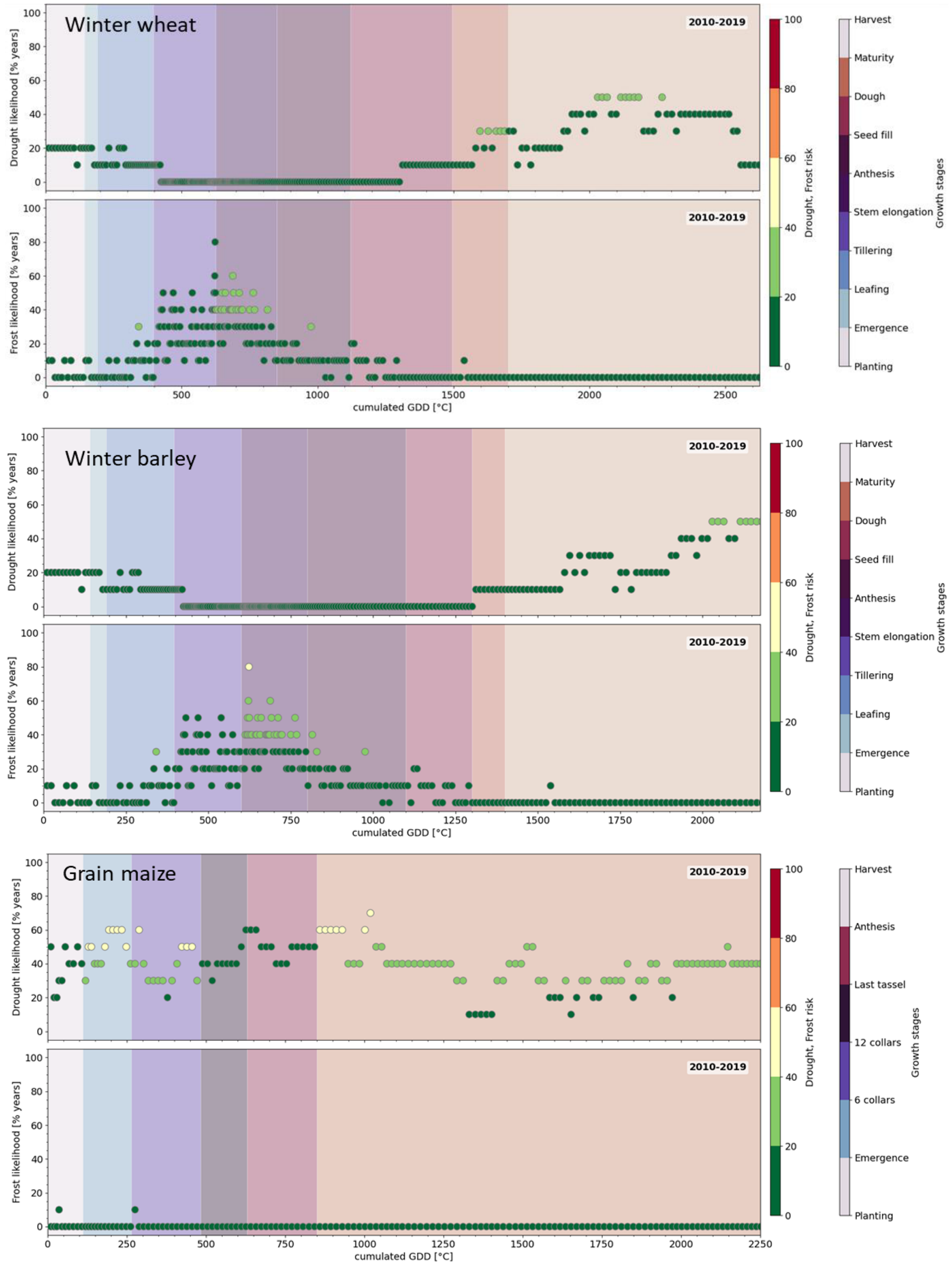

Figure 1. Drought and frost risk for winter wheat, winter barley and grain maize in Belgium, 2010-2019. 

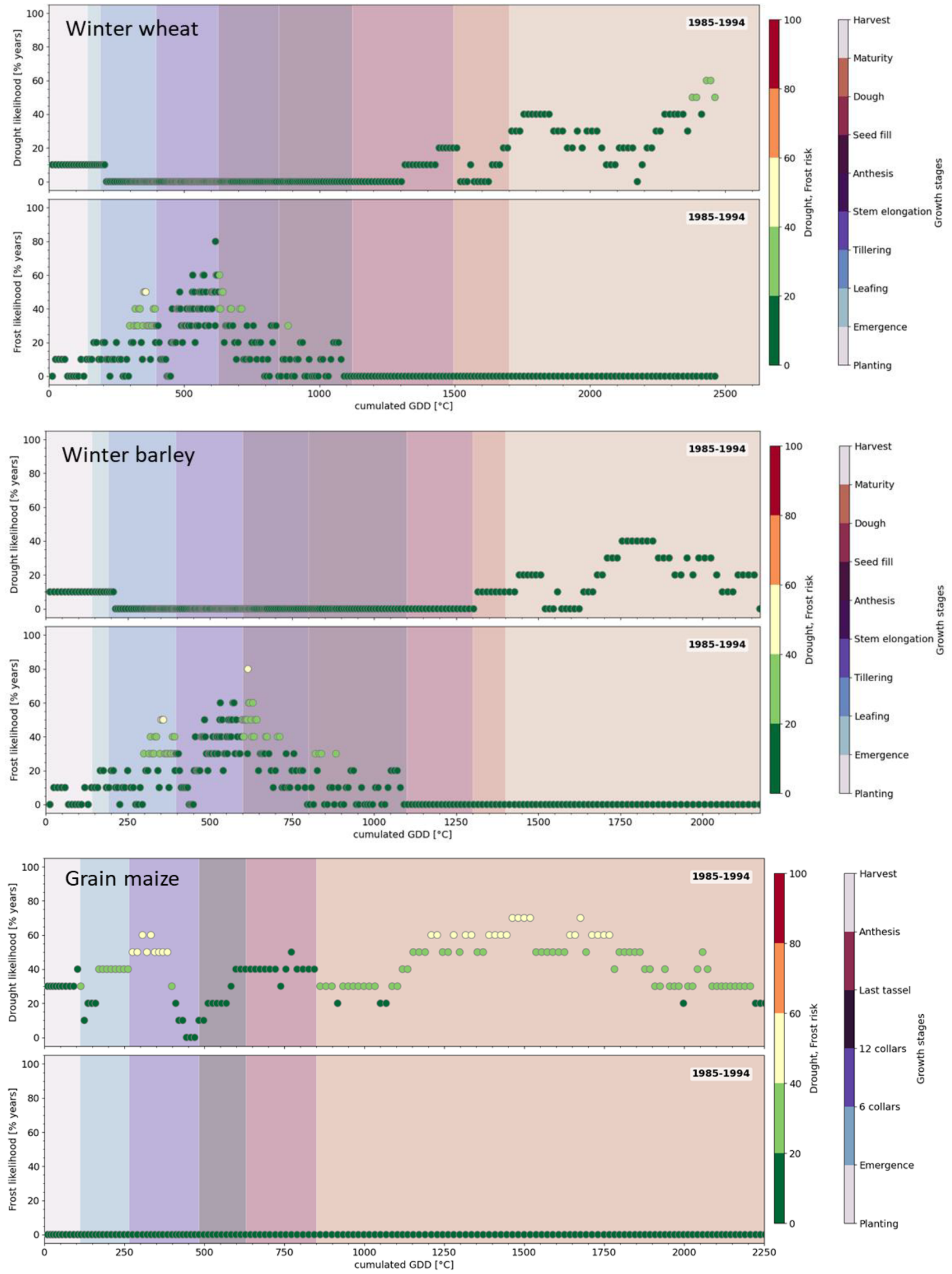

Figure 2. Drought and frost risk for winter wheat, winter barley and maize in Belgium, 1985-1994. 
Table 1. Crop characteristics of arable crops in Belgium (Gobin, 2010, 2012).

\begin{tabular}{lllll}
\hline & Unit & $\begin{array}{l}\text { Winter } \\
\text { barley }\end{array}$ & $\begin{array}{l}\text { Winter } \\
\text { wheat }\end{array}$ & Maize \\
\hline Tbase & Degree celsius & 4 & 4 & 8 \\
Sowing & Date & 15 Oct & 15 Oct & 1 May \\
Emergence & cGDD & 125 & 125 & 125 \\
Anthesis & cGDD & 800 & 850 & 850 \\
Maturity & cGDD & 1400 & 1700 & 1300 \\
Harvesting & Date & 15 Jul & 1 Aug & 30 Sep \\
\hline
\end{tabular}

water balance and crop growth (Gobin, 2010, 2018; Durgun et al., 2016). In addition to a shift in adverse temperature related events, crop development has advanced with up to $4 \mathrm{~d}$ per decade (Gobin, 2018), which warrants a dynamic modelling approach to simulate the different processes of crop phenology and weather risk occurrence. The onset of crop phenological stages was controlled by thermal time, in cumulative growing degree days (cGDD), using annual median planting dates and crop specific upper and lower threshold temperatures (Table 1; Gobin, 2010; Durgun et al., 2020). The soil water balance (Gobin, 2010) was calculated for a deep well developed soil with an effective rooting depth of $1 \mathrm{~m}$ and a crop readily available water holding capacity of $100 \mathrm{~mm}$. Drought was assessed in days with available soil water less than $3 \mathrm{~mm}$, and frost in temperatures below $0{ }^{\circ} \mathrm{C}$ for a period of more than $3 \mathrm{~h}$. A frequency analysis during the respective growth stages enabled a likelihood estimate (in \% of years) of the event during the different phenological stages. The impact was subsequently assessed in terms of sensitivity of the crop phenological stage with a higher impact rate for frost during emergence, tillering and stem elongation, and for drought during anthesis and grain filling. The risk results from multiplying the likelihood estimate and the impact rate. We compared the results for two decades: 1985-1994 and 2010-2019, and related the findings to extreme events that occurred during the pandemic year 2020.

\section{Results and discussion}

The likelihood estimate of frost for winter cereals is twofold: (1) early frost which covers a period from sowing around mid-October to the time when vernalisation commences, and (2) late frost after the vernalisation period. Though the likelihood of occurrence is high, the estimated impact rate is low (Fig. 1). Likewise the likelihood of late frost occurrence for maize is low, which is in tune with the date (14 May) of the 20-year return period for late frost occurrence in Belgium (Gobin, 2018). Despite the accelerated advancing of the growing season in a warming climate, frost occurrences will be lower for cereals. The likelihood of spring drought is fairly high and impacts cereals in different ways: during grain filling to maturity of winter wheat, during the dough stage to maturity of winter barley and during the early stages of grain maize. Summer drought impacts are highest for grain maize when drought episodes occur frequently during anthesis and grain filling.

The trend towards warmer and drier years is captured well in the changes of crop specific risks per decade when comparing 1985-1994 (Fig. 2) to 2010-2019 (Fig. 1). Winter wheat and winter barley in the last decade are subject to higher drought risk at the beginning of the growing season up to tillering as compared to the past (1985-1994). This is also the case at later development stages from dough to harvest and is more pronounced for winter wheat. Frost risk on the other hand decreased in the early development stages from leafing to tillering and stem elongation (Figs. 1 and 2). The drought risk for grain maize shifts earlier in the season with spring drought affecting earlier vegetative stages and summer drought posing a risk to anthesis.

The pandemic year 2020 was the warmest year on average since measurements began in 1833 (RMI, 2021), and included a $12 \mathrm{~d}$ heat wave during the beginning of august. April and May were the driest months ever recorded, and contributed to 2020 being the fourth driest year since 1981 . During the pandemic year harvests were earlier and crop development was fast due to warm temperatures. However, in the first half of May maize growth was slow due to the persistent spring drought and some very cold days. The $\mathrm{Au}-$ gust heat wave hit flowering or grain filling stages with yield loss as a consequence. Winter cereal yields were variable and depended largely on the soil available water conditions. Overall the weather conditions were favourable during anthesis, and ripening benefitted from prolonged drought. The 2020 weather could be related to the general patterns that demonstrated increased risks towards earlier stages in the growing season (Figs. 1 and 2).

\section{Conclusions}

The growing season length, the succession of phenological stages, the frost-free period, and water deficit are climatic constraints that have changed on average during the past decades. Therefore the analysis will be extended to include a longer timeframe and enable a comparison of risks between different periods in an already changing climate. These emerging patterns of shifting probability densities for different extreme events and their rated impacts enable climate risk services for arable farming now and under climate change.

Data availability. Data are available upon request.

Author contributions. AG, NA and CR designed the experiments. KG, NA, and CR developed the diagrams integrating climate 
and crop information. AG prepared the manuscript with contributions from all co-authors.

Competing interests. The authors delcare that they have no conflict of interest.

Special issue statement. This article is part of the special issue "Applied Meteorology and Climatology Proceedings 2020: contributions in the pandemic year".

Acknowledgements. The authors thank the editor and two anonymous referees for reviewing the manuscript.

Financial support. The authors acknowledge funding from the European Union's Horizon 2020 Research and Innovation Programme, under grant agreements no. 818187 (STARGATE) and no. 777549 (EUXDAT).

Review statement. This paper was edited by Josef Eitzinger and reviewed by two anonymous referees.

\section{References}

Bindi, M. and Olesen, J.: The responses of agriculture in Europe to climate change, Reg. Environ. Change, 11, S151-S158, https://doi.org/10.1007/s10113-010-0173-x, 2011.

Ciais, P., Reichstein, M., Viovy, N., Granier, A., Ogée, J., Allard, V., Aubinet, M., Buchmann, N., Bernhofer, C., Carrara, A., and Chevallier, F.:: Europe-wide reduction in primary productivity caused by the heat and drought in 2003, Nature, 437, 529-534, 2005.

Drepper, B., Gobin, A., Remy, S., and Van Orshoven, J.: Comparing Apple and Pear Phenology and Model Performance: What Seven Decades of Observations Reveal, Agronomy, 10, 73, https://doi.org/10.3390/agronomy10010073, 2020.

Durgun, Y.Ö., Gobin, A., Gilliams, S., Duveiller, G., and Tychon, B.: Testing the Contribution of Stress Factors to Improve Wheat and Maize Yield Estimations Derived from Remotely-Sensed Dry Matter Productivity, Remote Sens., 8, 170, https://doi.org/10.3390/rs8030170, 2016.

Durgun, Y.Ö., Gobin, A., Duveiller, G., and Tychon, B.: A study on trade-offs between spatial resolution and temporal sampling density for wheat yield estimation using both thermal and calendar time, Int. J. Appl. Earth Obs. Geoinform., 86, 101988, https://doi.org/10.1016/j.jag.2019.101988, 2020.

Fischer, E. M., Seneviratne, S. I., Vidale, P. L., Lüthi, D., and Schär, C.: Soil moisture-atmosphere interactions during the 2003 European summer heatwave, J. Climate, 20, 5081-5099, 2007.

Gobin, A.: Modelling climate impacts on arable yields in Belgium, Clim. Res., 44, 55-68, https://doi.org/10.3354/cr00925, 2010.

Gobin, A.: Impact of heat and drought stress on arable crop production in Belgium, Nat. Hazards Earth Syst. Sci., 12, 1911-1922, https://doi.org/10.5194/nhess-12-1911-2012, 2012.
Gobin, A.: Weather related risks in Belgian arable agriculture, Agricult. Syst., 159, 225-236, https://doi.org/10.1016/j.agsy.2017.06.009, 2018.

Kahiluoto H., Kaseva, J., Balek, J., Olesen, J. E., Ruiz-Ramos, M., Gobin, A., Kersebaum, K. C., Takáč, J., Ruget, F., Ferrise, R., Bezak, P., Capellades, G., Dibari, C., Mäkinen, H., Nendel, C., Ventrella, D., Rodríguez, A., Bindi, M., and Trnka, M.: Decline in climate resilience of European wheat, P. Natl. Acad. Sci. USA, 116, 123-128, https://doi.org/10.1073/pnas.1804387115, 2019.

Mäkinen, H., Kaseva, J., Trnka, M., Balek, J, Kersebaum, K. C., Nendel, C., Gobin, A., Olesen, J. E., Bindi, M., Ferrise, R., Moriondo, M., Rodríguez, A., Ruiz-Ramos, M., Takáč, J., Pavol, B., Ventrella, D., Ruget, F., Capellades, G., and Kahiluoto, H.: Sensitivity of European wheat to extreme weather, Field Crops Res., 222, 209-217, https://doi.org/10.1016/j.fcr.2017.11.008, 2018.

Reidsma, P., Ewert, F., Boogaard, H., and Van Diepen, K.: Regional crop modelling in Europe: The impact of climatic conditions and farm characteristics on maize yields, Agricult. Syst., 100, 51-60, https://doi.org/10.1016/j.agsy.2008.12.009, 2009.

RMI: Royal Meteorological Institute, available at: https://www.meteo.be/nl/info/nieuwsoverzicht, last access: 11 February 2021.

Schär, C., Vidale, P. L., Lüthi, D., Frei, C., Häberli, C., Liniger, M., and Appenzeller, C.: The role of increasing temperature variability in European summer heat waves, Nature, 427, 332-336, https://doi.org/10.1038/nature02300, 2004.

Termonia, P., Willems, P., Van Lipzig, N., van Ypersele, J.P., Marbaix, P., Fettweis, X., De Ridder, K., Gobin, A., Stavrakou, T., Luyten, P., Pottiaux, E., and Van Schaeybroeck, B.: The CORDEX.be project as a foundation for climate services in Belgium, Clim. Serv., 11, 49-65, https://doi.org/10.1016/j.cliser.2018.05.001, 2018.

Trenberth, K. E., Jones, P. D., Ambenje, P., Bojariu, R., Easterling, D., Klein Tank, A., Parker, D., Rahimzadeh, F., Renwick, J. A., Rusticucci, M., Soden, B., and Zhai, P.: Observations: surface and atmospheric climate change, in: Climate Change 2007: The Physical Science Basis, Contribution of Working Group I to the Fourth Assessment Report of the Intergovernmental Panel on Climate Change, edited by: Solomon, S., Qin, D., Manning, M., Chen, Z., Marquis, M., Averyt, K. B., Tignor, M., and Miller, H. L., Cambridge University Press, Cambridge, 235-336, 2007.

Trnka, M., Olesen, J. E., Kersebaum, K. C., Rötter, R. P., Brázdil, R., Eitzinger, J., Jansen, S., Skjelvåg, A. O., Peltonen-Sainio, P., Hlavinka, P., Balek, J., Eckersten, H., Gobin, A., Vučetić, V., Dalla-Marta, A., Alexandrov, V., Semerádová, D., Štěpánek, P., Svobodová, E., and Rajdl, K.: Changing regional weather-crop yield relationship across Europe between 1901 and 2012, Clim Res., 70, 195-214, https://doi.org/10.3354/cr01426, 2016.

Vanwindekens, F. M., Gobin, A., Curnel, Y., and Planchon, V.: A new approach for mapping vulnerability of agroecosystems based on experts' knowledge, Math. Geosci., 50, 679-696, https://doi.org/10.1007/s11004-018-9730-5, 2018.

Zamani, S., Gobin, A., Van de Vyver, H., and Gerlo, J.: Atmospheric drought in Belgium - Statistical analysis of precipitation deficit, Int. J. Climatol., 36, 3056-3071, https://doi.org/10.1002/joc.4536, 2015. 